IZA DP No. 9811

Energy Boom and Gloom? Local Effects of Oil and Natural Gas Drilling on Subjective Well-Being

Karen Maguire

John V. Winters

March 2016 


\title{
Energy Boom and Gloom? Local Effects of Oil and Natural Gas Drilling on Subjective Well-Being
}

\author{
Karen Maguire \\ Oklahoma State University
}

John V. Winters

Oklahoma State University

and IZA

\author{
Discussion Paper No. 9811 \\ March 2016
}

IZA

P.O. Box 7240

53072 Bonn

Germany

Phone: +49-228-3894-0

Fax: +49-228-3894-180

E-mail: iza@iza.org

Any opinions expressed here are those of the author(s) and not those of IZA. Research published in this series may include views on policy, but the institute itself takes no institutional policy positions. The IZA research network is committed to the IZA Guiding Principles of Research Integrity.

The Institute for the Study of Labor (IZA) in Bonn is a local and virtual international research center and a place of communication between science, politics and business. IZA is an independent nonprofit organization supported by Deutsche Post Foundation. The center is associated with the University of Bonn and offers a stimulating research environment through its international network, workshops and conferences, data service, project support, research visits and doctoral program. IZA engages in (i) original and internationally competitive research in all fields of labor economics, (ii) development of policy concepts, and (iii) dissemination of research results and concepts to the interested public.

IZA Discussion Papers often represent preliminary work and are circulated to encourage discussion. Citation of such a paper should account for its provisional character. A revised version may be available directly from the author. 


\section{ABSTRACT \\ Energy Boom and Gloom? Local Effects of Oil and Natural Gas Drilling on Subjective Well-Being ${ }^{*}$}

The United States experienced a considerable increase in oil and natural gas extraction in recent years due to technological advancements including horizontal drilling and hydraulic fracturing. Increased energy development likely creates both benefits and costs, but the net effects for local residents are not well understood. This paper examines effects of conventional and horizontal oil and natural gas drilling in Texas on subjective assessments of life-satisfaction and bad mental health days for nearby residents. Horizontal drilling has statistically significant deleterious effects on well-being, but the effects are driven by the Dallas-Fort Worth (DFW) metropolitan area, an area with both very high levels of horizontal drilling and a large urban population.

JEL Classification: I10, Q40

Keywords: energy, drilling, subjective well-being, mental health, natural gas, environment

Corresponding author:

John V. Winters

Department of Economics and Legal Studies

Oklahoma State University

331 Business Building

Stillwater, Oklahoma 74078

USA

E-mail: jvwinte@okstate.edu

\footnotetext{
* Funding to purchase the data used in this research was provided by the Oklahoma State University Department of Economics and Legal Studies. All findings are those of the authors and do not necessarily represent the opinions of the University, the Department, or any other parties.
} 


\section{Introduction}

Implementation of horizontal drilling and hydraulic fracturing technologies has led to a resurgence in oil and natural gas production in the United States (Weinstein 2014). ${ }^{1}$ This has increased development activity in energy rich states, including Texas (Brown 2014). As of 2014, Texas dominated all other states in oil and gas production, ranking first for both oil and natural gas produced. Texas is also the top state in terms of proved oil reserves, largely from shale and tight oil formations, which require hydraulic fracturing technology for extraction (EIA Texas 2014). In addition, Texas contributed 29 percent of U.S. natural gas production, again largely from shale resources (EIA 2014; EIA Texas 2014). The increase in production is matched by an increase in wells drilled. In 2005, Texas oil and natural gas producers drilled approximately 12,000 wells; this increased to approximately 17,000 in $2008 .^{2}$ While there was a decline after 2008, drilling rebounded quickly; see Figure 1 (Texas RRC 2015).

In this paper, we examine the role of oil and gas development on subjective well-being (SWB) across Texas. Previous literature has examined the local economic impacts of oil and gas development, with mixed results (Kinnaman 2011; Muehlenbachs et al. 2015; Munasib and Rickman 2015; Paredes et al. 2015; Weber 2012, 2014). Rather than focusing on the potential for local spillovers from increased employment and income in the energy sector, this paper examines the effects on individuals' SWB. There is potential for positive impacts due to increased income both within the energy sector and in supporting sectors from increased oil and gas development activity. However, there are also potential negative impacts due to increased road noise and

\footnotetext{
${ }^{1}$ Horizontal drilling and hydraulic fracturing technologies have existed for decades. The combined use of these technologies led to the "shale revolution", which started in the Barnett Shale in Texas in 1998 and spread across the U.S. in the mid-2000s (Fitzgerald 2013). Throughout this paper, the term horizontal drilling refers to the combined use of these technologies.

${ }^{2}$ Wells drilled include oil and natural gas wells and dry holes.
} 
congestion, earthquakes, and potential environmental impacts including noise, air, and water pollution from drilling, chemical injections, and wastewater disposal (Ellsworth 2013; Fry et al. 2015; Keranen et al. 2014; Wang et al. 2014). ${ }^{3}$ In order to determine whether oil and gas drilling is having a net positive or negative effect, we examine the effects of county level oil and gas drilling activity on individual subjective well-being measures from 2005 through 2010, a period of heightened oil and gas development in Texas.

Texas has long been a major oil and gas producer in the United States. Hydraulic fracturing technology has allowed it to access once economically infeasible resources, both oil and natural gas. This has substantially increased proved reserves and led to significant development, particularly in the Eagle Ford and Barnett Shale Plays and the Permian Basin areas of Texas (EIA Texas 2014). Due to the nature of the technology, hydraulically fractured (horizontal) wells require a larger footprint during the drilling process for the storage of water used in the fracturing process. This may increase road noise and congestion. In addition, environmental concerns particularly regarding water quality are centered on hydraulically fractured rather than conventional wells (Fitzgerald 2013). In this analysis, we consider separately the effects of conventional and horizontally drilled wells in order to determine if there are differential impacts from the two types of drilling. We also examine separate sub-samples of geographic areas within Texas, an important consideration given that both population and drilling are unequally dispersed across the state.

Previous researchers have shown differences in SWB across areas of the U.S. (Oswald and Wu 2010, 2011; Sander 2011; Glaeser et al. 2016; Winters and Li 2016). Oswald and Wu (2010) show that state SWB differentials correlate with hedonic quality of life rankings. Other

\footnotetext{
${ }^{3}$ Increases in earthquake activity have been tied to injection wells, which are used to inject waste water that is produced by the hydraulic fracturing process.
} 
researchers have examined effects of various environmental factors. For example, reductions in air pollution, increases in green space, ecosystem preservation, and other environmental improvements have been found to increase SWB (Abdallah et al. 2008; Ambrey and Fleming 2014; Brereton et al. 2008; Cuñado and Pérez de Gracia, 2013; Moro et al. 2008; Smyth et al. 2008; Vemuri and Costanza 2006; Welsch 2006). Researchers have also examined SWB relationships with individual characteristics such as income, employment status, education, marital status, presence of children, age, sex, race, and ethnicity (Clark and Oswald 1994; Winkelmann and Winkelmann 1998; Gardner and Oswald 2007; Oswald and Wu 2011; MacKerron 2012). In general, SWB exhibits expected relationships with income and employment, at least cross-sectionally. ${ }^{4}$

However, we are unaware of any previous research that has examined potential effects of oil and gas drilling on SWB for nearby residents. We attempt to fill this important gap in the research literature. Our main SWB measure is based on individuals' subjective assessments of their own life-satisfaction, but we also examine effects on the self-reported number of bad mental health days in the past month.

Previewing results, we find that horizontal drilling has statistically significant deleterious effects on subjective well-being for our full sample for both SWB measures that we consider. However, the adverse effects are concentrated in the Dallas-Fort Worth (DFW) metropolitan area, and no statistically significant adverse effect of drilling is found outside of DFW. DFW is a

\footnotetext{
${ }^{4}$ Easterlin (1974) and others have suggested that increases in average incomes do not always translate into increased happiness. This paradoxical result may occur because economic growth raises expected incomes, causing individuals to need higher actual incomes to obtain a given level of happiness (Easterlin 1995; Easterlin 2001). Individual happiness may also be affected by one's financial success relative to peers, so that rising incomes for all do not increase happiness. However, the "Easterlin Paradox" is still quite controversial with dissenting conclusions reached by some other scholars (Veenhoven and Hagerty 2006; Sacks, Stevenson, and Wolfers 2010; Diener, Tay, and Oishi 2013). Easterlin (2016) emphasizes that while short run economic growth increases SWB, it is long run growth that is unrelated to SWB.
} 
very unique metropolitan area that contains both very high levels of horizontal drilling and a large urban population. The DFW metropolitan area has more than six million people and sits atop the Barnett Shale, the oldest and most developed shale play in the U.S., making it "ground zero" for urban shale development (Fry et al. 2015). Consistent with our results, the DFW area has experienced intense opposition from residents to urban shale development, leading to numerous drilling ordinances including a hydraulic fracturing ban adopted by Denton, TX in November 2014. The Denton ban was later repealed after state legislation prevented Texas localities from banning fracking, but opposition to urban drilling continues (Fry et al. 2015).

Oil and gas drilling creates both costs and benefits. The benefits accrue to mineral owners and workers in energy and related industries, while the costs largely accrue to local residents. Mineral owners are typically not local residents in Texas (Fry et al. 2015) or other states (Brown et al. 2015). While some local residents are employed in local energy extraction and related industries, the share is relatively small in large industrially diverse metropolitan areas like DFW. The net effects of drilling on well-being in Texas depend on location. Net effects are not statistically different from zero outside of DFW. However, for the average DFW resident, the costs of drilling in the DFW area exceed the benefits and reduce their subjective well-being.

\section{Materials and Methods}

The data for this study come from two sources, the Texas Railroad Commission (RRC) and the Behavioral Risk Factor Surveillance System (BRFSS) from 2005 through 2010. The RRC database includes information on every oil and natural gas well drilling permit issued in Texas since 1976 (Texas RRC 2015). ${ }^{5}$ This includes the spud date, i.e., the date in which the drilling

\footnotetext{
5 The database is available for purchase from the Texas RRC. The data are constructed from the Drilling Permit Master and Trailer Plus Latitudes and Longitudes.
} 
process began. ${ }^{6}$ The potential disturbance from oil and gas development occurs primarily during the drilling process and for this reason all observations with a spud date in the relevant periods are included in the analysis. The data were aggregated to the county-month level in order to construct measures of oil and natural gas drilling activity; conventional and horizontal wells were examined separately. ${ }^{7}$

The 2005-2010 BRFSS asked about self-reported SWB and includes county identifiers for respondents living in 153 of Texas' 254 counties; small counties are unidentifiable to preserve confidentiality. We estimate variants of the following linear regression equation for individual $i$ in county $c$ in month-year $t$ :

$$
Y_{i c t}=X_{i c t} \beta+Z_{c t} \theta+\Gamma_{c}+\Pi_{t}+\varepsilon_{i c t},
$$

where $Y_{i c t}$ is a well-being dependent variable; $X_{i c t}$ includes individual controls for sex, race/ethnicity, five-year age group, marital status, education level, number of adults in the household, and household child-adult ratio; $Z_{c t}$ includes two separate variables for the numbers of conventional wells and horizontal wells drilled in the last 12 months; $\Gamma_{s}$ includes county fixed effects; $\Pi_{t}$ includes month-year effects. County fixed effects control for time-invariant county characteristics that might affect SWB and their inclusion means that identifying variation comes from changes within counties over time. Our primary drilling measures are total counts, but we also examine the robustness to using drilling counts normalized by county land area. We do not control for income or employment status, because they may be mechanisms by which energy extraction affects well-being; our estimates measure the overall effects of oil and gas drilling without identifying or controlling for any specific mechanisms. ${ }^{8}$ We examine two dependent

\footnotetext{
${ }^{6}$ Oil and gas wells categorized as drill, other, reenter and recompletion are included in the analysis.

${ }^{7}$ Horizontal wells include those flagged as horizontal and directional in the RRC data.

${ }^{8}$ In results not shown but available by request, we estimated regression equations that included dummy variable controls for income and employment status. Results are similar to those reported below.
} 
variables. The first is self-reported life-satisfaction on a 1-4 scale, representing four responses: Very dissatisfied, Dissatisfied, Satisfied, or Very Satisfied. ${ }^{9}$ The second is the self-reported number of bad mental health days in the past month. Persons with missing or invalid responses are excluded. The analysis is also restricted to ages 18-85. Standard errors are clustered by county to account for serial correlation within counties. Summary statistics for the full sample are reported in Table 1.

We also recognize that drilling activity is quite unevenly distributed across areas. Figures 2 and 3 illustrate conventional and horizontal drilling by county across Texas for year 2010; earlier years show similar geographic patterns. These figures also indicate the locations of major Texas cities including Austin, Dallas, El Paso, Fort Worth, Houston, and San Antonio. These are the six most populous cities and principal cities of the five largest metropolitan statistical areas (MSA) in Texas. Figure 2 shows that conventional drilling is relatively modest near the major population centers. Horizontal drilling is generally minimal near major population centers with the exception of the DFW MSA. In fact, the DFW MSA includes the five counties with the highest total horizontal drilling levels in Texas over the $2005-2010$ period. ${ }^{10}$ We examine potential heterogeneous effects across areas by estimating our regressions for separate subsamples of geographic areas within Texas, including separate examination of the DFW MSA. Summary statistics for the main variables in our study are reported in Table 2 for the subsamples that we consider.

\section{Results}

\footnotetext{
${ }^{9}$ The large number of fixed effects make ordered probit and logit estimation less desirable due to difficulties achieving convergence; linear models are common in the SWB literature, in part because of ease in estimation and interpretation.

${ }^{10}$ Alphabetically, the top five counties are Denton, Johnson, Parker, Tarrant, and Wise.
} 
Our main results are reported in Table 3. Column 1 reports results using self-reported life satisfaction as the dependent variable, and column 2 examines the number of bad mental health days. Note that coefficient interpretation is in the opposite direction for our two outcomes. Desirable outcomes increase life satisfaction and reduce bad mental health days. Panel A reports results for the full sample. Panel B reports results for the Dallas-Fort Worth MSA and Panel C reports results for all areas excluding the DFW MSA. The non-DFW sample is further separated into large MSAs in Panel D and other areas in Panel E. Large MSAs include those with a year 2000 population greater than one million. The other areas in Panel E include identifiable nonmetropolitan counties, small MSAs, and medium-population MSAs.

The overall results for the full sample in Panel A of Table 3 suggest that conventional drilling has no statistically significant effect on either subjective life-satisfaction or the number of bad mental health days. Interestingly, the positive coefficient on life satisfaction and negative coefficient on bad mental health days may weakly suggest that conventional drilling has positive effects on well-being. However, we cannot make strong inferences about full sample effects of conventional drilling. ${ }^{11}$ For horizontal drilling, the effects are clearer. Horizontal drilling statistically significantly reduces life satisfaction and increases bad mental health days for the full sample. Interpreting the coefficient magnitudes requires considering the summary statistics for horizontal drilling. The coefficient of -0.0001 for the effects of horizontal drilling on life satisfaction combined with the standard deviation for horizontal drilling of 143.9 suggests that a one standard deviation increase in horizontal drilling reduces life satisfaction on average by 0.0144 , i.e., about 1.4 percent of the sample would be moved to a lower life-satisfaction

\footnotetext{
${ }^{11}$ Estimating results for each drilling variable in separate regressions yields nearly identical results, ruling out possible concerns that the drilling variables might be highly collinear. Their raw correlation for the full sample is only -0.019 .
} 
category. This is a meaningful effect with the potential to considerably reduce subjective wellbeing in areas with high levels of drilling. Similarly, the coefficient of 0.00152 in column 2 suggests that a one standard deviation increase in horizontal drilling would on average increase bad mental health days by 0.22 per month, which is again a meaningful effect.

Panel B of Table 3 examines the Dallas-Fort Worth MSA sub-sample. Column 1 shows negative effects on life satisfaction from both conventional and horizontal drilling. The conventional drilling coefficient of -0.00124 is statistically significant at the ten percent level and the horizontal drilling coefficient of -0.00007 is significant at the five percent level. The raw magnitudes of these coefficients might suggest conventional drilling has a larger effect, but we must also consider the dispersion in the variables. Multiplying these coefficients by the drilling standard deviations in Panel B of Table 2 suggests that a one standard deviation increase in conventional drilling decreases life satisfaction by 0.0143 while a one standard deviation increase in horizontal drilling decreases life satisfaction by 0.0168 . The effect for horizontal drilling is comparable to the full sample results in Panel A, but conventional drilling had no adverse effect on average in the full sample. The Column 2 results for bad mental health days show no adverse effect of conventional drilling. However, horizontal drilling significantly increases bad mental health days; the coefficient of 0.00242 suggests that a one standard deviation in horizontal drilling in the DFW MSA increases bad mental health days by 0.58 , a magnitude considerably larger than that implied by the full sample results in Panel A.

Panel C of Table 3 reports results for the full sample excluding the DFW MSA. The results for both drilling variables are statistically insignificant at conventional levels for both outcomes. The coefficients for both are positive in the life satisfaction regression weakly suggesting that drilling may if anything improve life satisfaction outside of DFW. The results for bad mental 
health days are especially small relative to standard errors. Panel D reports results for large MSAs other than DFW. None of the estimates are statistically significant, but coefficient estimates again weakly suggest possible improvements to SWB from drilling activity. However, drilling activity is relatively low in large MSAs other than DFW. Panel E reports results for the sample that excludes all large MSAs. All coefficients are again statistically insignificant with positive estimates for drilling variables in both the life satisfaction and bad mental health regressions.

The results in Table 3 suggest adverse effects on SWB from horizontal drilling that is driven by effects in the DFW MSA. Outside of the DFW MSA, drilling has either no effect or perhaps a weak positive effect on SWB. Furthermore, while conventional drilling is generally modest in the DFW MSA, the high rate of horizontal drilling may amplify adverse effects of conventional drilling on life satisfaction.

We next examine the robustness of our main results to measuring wells drilled per land area rather than the raw counts of wells drilled. Results are reported in Table 4 with full sample results in Panel A and DFW MSA results in Panel B. The pattern of results is very similar to Table 3. For the full sample in Panel A, conventional drilling has small insignificant coefficients for both outcomes, and horizontal drilling has a significant negative effect on life satisfaction and a significant positive effect on bad mental health days. For the DFW MSA in Panel B, conventional wells have a significant negative effect on life satisfaction but a small insignificant coefficient for bad mental health days. Horizontal drilling again has significant negative effects on life satisfaction and significant positive effects on bad mental health days in the DFW MSA. Furthermore, the drilling magnitudes implied by combining Panel A and B coefficients with standard errors are very comparable to the implied magnitudes from Table 3. Additionally, using 
wells drilled per land area for the other subsamples in Table 3 yields comparable results to those in Table 3, i.e., coefficients estimates are not statistically significant. These results are available by request. Thus, using wells drilled per land area does not meaningfully affect our results.

We next estimate separate results for males and females to see if the effects differ by sex. For example, differences by sex could result from differing employment effects or differential sensitivity to environmental concerns. Previous literature indicates that men are more likely to be employed in energy industries and women are more likely to be concerned about the environment (Catalyst 2012, Xiao and McCright 2015). Results by sex are reported in Table 5; Panel A examines the full sample and Panel B examines the DFW MSA. Results for the other subsamples are generally imprecise and thus not reported.

Separating by sex shows that the negative effect on life satisfaction from horizontal drilling is experienced by women. The female horizontal well coefficient in Panel A is -0.00020 and statistically significant, white the male coefficient is zero for practical purposes. The female coefficient combined with the summary statistics suggests that a one standard deviation increase in horizontal drilling would decrease female life satisfaction by 0.029 , i.e., about three percent of women would be moved to a lower life-satisfaction category. This is a sizable effect. The adverse effect of horizontal drilling on bad mental health in Panel A of Table 5 is comparable across sexes with significant coefficients of 0.00170 and 0.00155 for males and females, respectively.

The results in Panel B suggest that women in the DFW MSA suffer reduced life satisfaction from both conventional and horizontal drilling, while male life satisfaction is not significantly affected. The coefficients of -0.00197 and -0.00011 for conventional and horizontal drilling combined with their standard deviations imply that a one standard deviation increase in 
conventional drilling reduces DFW MSA female life satisfaction by 0.023 and a one standard deviation increase in horizontal drilling reduces DFW MSA female life satisfaction by 0.026 ; both of these are large effects. For bad mental health days, the adverse effects of horizontal drilling in the DFW MSA are born by both males and females, but males now bear a much larger effect. The statistically significant male and female coefficients of 0.00388 and 0.00145 imply that a one standard deviation increase in horizontal drilling increases bad mental health days by 0.93 for men and 0.34 for women.

The inconsistent sex differences between the two dependent variables should not be surprising given that they are similar but distinct measures. Their raw correlation for the full sample is -0.347 . Drilling appears to affect life satisfaction and bad mental health days in unique ways that differ by sex. More important, however, is that both the life satisfaction and bad mental health days measures exhibit adverse effects from horizontal drilling in the DFW MSA.

\section{Conclusion}

This paper examines the distinct effects of conventional and horizontal oil and gas drilling in Texas counties on subjective self-assessments of life-satisfaction and bad mental health days for nearby residents. Horizontal drilling has negative effects on self-reported well-being measures, but the effects are driven by high levels of horizontal drilling in the Dallas-Fort Worth MSA.

Adverse effects on life satisfaction are experienced exclusively by women, but adverse effects on bad mental health days are experienced by both sexes with potentially larger effects for men.

Horizontal drilling involves new techniques that have opened up large shale reserves that were previously unattainable. This has greatly increased U.S. energy production and reduced American dependence on foreign energy sources. Rising energy supply has also contributed to 
decreased prices for consumers. There are certainly benefits to horizontal drilling both in areas where the energy is produced and consumed. However, there are certainly costs as well. External costs related to congestion, pollution, and unsightliness are likely to be disproportionately born by residents living in proximity to where the horizontal drilling is done. We show that local residents in the DFW MSA are on net made worse off by horizontal drilling. Several communities, including Denton, Texas, that are impacted by high levels of horizontal drilling have attempted to restrict its use and despite their failure to do so, local residents remain concerned (Malewitz 2015). While falling natural gas prices have reduced drilling and eased the conflict for now, in the future, both policy makers and producers will have to consider ways to mitigate local urban impacts in order to continue to develop these resources.

The adverse effects of horizontal drilling are generally not found outside of the DFW MSA. Impacts in areas with lower rates of horizontal drilling and in more sparsely populated areas of Texas appear less problematic and may even be net beneficial to local residents. The DFW MSA, however, experienced especially high horizontal drilling levels in highly populous urban areas. For the average DFW resident, the costs of horizontal drilling exceeded the benefits and reduced their subjective well-being. 


\section{References}

Abdallah, Saamah, Sam Thompson, and Nic Marks. 2008. Estimating Worldwide Life Satisfaction. Ecological Economics, 65(1): 35-47.

Ambrey, Christopher, and Christopher Fleming. 2014. Public Greenspace and Life Satisfaction in Urban Australia. Urban Studies, 51(6), 1290-1321.

Brereton, Finbarr, J. Peter Clinch, and Susana Ferreira. 2008. Happiness, Geography and the Environment. Ecological Economics, 65(2), 386-396.

Brown, Jason P. 2014. Production of Natural Gas from Shale in Local Economies: A Resource Blessing or Curse? Federal Reserve Bank of Kansas City, Economic Review, 99(1), 119-147.

Brown, Jason P., Timothy R. Fitzgerald, and Jeremy G. Weber. 2015. Capturing Rents from Natural Resource Abundance: Private Royalties from U.S. Onshore Oil \& Gas Production. Federal Reserve Bank of Kansas City Working Paper 15-04.

Catalyst. 2012. Women in Gas, Mining \& Oil in Australia, Canada \& the U.S. http://www.catalyst.org/knowledge/women-gas-mining-oil-australia-canada-us (Accessed 08/14/15).

Clark, Andrew E., and Andrew J. Oswald. 1994. Unhappiness and Unemployment. The Economic Journal, 104(424), 648-659.

Cuñado, Juncal, and Fernando Pérez de Gracia. 2013. Environment and Happiness: New Evidence for Spain. Social Indicators Research, 112(3), 549-567.

Diener, Ed, Louis Tay, and Shigehiro Oishi. 2013. Rising Income and the Subjective Wellbeing of Nations. Journal of Personality and Social Psychology, 104(2), 267-276.

Easterlin, Richard A. 1974. Does Economic Growth Improve the Human Lot? Some Empirical Evidence. In P. A. David and M. W. Reder (Eds.), Nations and Households in Economic Growth: Essays in Honor of Moses Abramowitz. Academic Press, Orlando, FL, pp. 89-125.

Easterlin, Richard A. 1995. Will Raising the Incomes of All Increase the Happiness of All? Journal of Economic Behavior \& Organization, 27(1), 35-47.

Easterlin, Richard A. 2001. Income and Happiness: Towards a Unified Theory. Economic Journal, 111(473), 465-484.

Easterlin, Richard A. 2016. Paradox Lost? IZA Discussion Paper No. 9676.

EIA. 2014. Texas: State Profile and Energy Estimates. http://www.eia.gov/state/?sid=TX (Accessed 07/23/15).

EIA Texas. 2014. Texas Energy Highlights. http://www.eia.gov/state/?sid=TX (Accessed 07/23/15).

Ellsworth, W. L. (2013). Injection-induced earthquakes. Science, 341(6142), 1225942.

Fitzgerald, Timothy 2013. Frackonomics: Some Economics of Hydraulic Fracturing. Case W. Res. L. Rev., 63, 1337. 
Fry, Matthew, Adam Briggle, and Jordan Kincaid. 2015. Fracking and Environmental (In) Justice in a Texas City. Ecological Economics, 117, 97-107.

Gardner, Jonathan, and Andrew J. Oswald. 2007. Money and Mental Wellbeing: A Longitudinal Study of Medium-Sized Lottery Wins. Journal of Health Economics, 26(1), 49-60.

Glaeser, Edward L., Joshua D. Gottlieb, and Oren Ziv. 2016. Unhappy Cities. Journal of Labor Economics, Forthcoming.

Keranen, K. M., Weingarten, M., Abers, G. A., Bekins, B. A., \& Ge, S. (2014). Sharp increase in central Oklahoma seismicity since 2008 induced by massive wastewater injection. Science, 345(6195), 448-451.

Kinnaman, Thomas C., 2011. The Economic Impact of Shale Gas Extraction: A Review of Existing Studies. Ecological Economics, 70(7), 1243-1249.

MacKerron, George. 2012. Happiness Economics from 35000 Feet. Journal of Economic Surveys, 26(4), 705-735.

Malewitz, Jim. 2015. After Fracking Ban, Denton Residents Ponder Next Steps. The Texas Tribune. https://www.texastribune.org/2015/06/03/more-questions-answers-denton-pondersnext-steps/ (accessed 03/04/16)

Moro, Mirko, Finbarr Brereton, Susana Ferreira, and J. Peter Clinch. 2008. Ranking Quality of Life Using Subjective Well-being Data. Ecological Economics, 65(3), 448-460.

Muehlenbachs, Lucija, Elisheba Spiller, and Christopher Timmins. 2015. The Housing Market Impacts of Shale Gas Development. American Economic Review, 105, 3633-59.

Munasib, Abdul and Dan S. Rickman. 2015. Regional Economic Impacts of the Shale Gas and Tight Oil Boom: A Synthetic Control Analysis. Regional Science and Urban Economics, 50, $1-17$.

Oswald, Andrew J. and Stephen Wu. 2010. Objective Confirmation of Subjective Measures of Human Well-being: Evidence from the USA. Science, 327, 576-579.

Oswald, Andrew J. and Stephen Wu. 2011. Well-being across America. Review of Economics and Statistics, 93(4), 1118-1134.

Paredes, Dusan, Timothy Komarek, and Scott Loveridge. 2015. Income and Employment Effects of Shale Gas Extraction Windfalls: Evidence from the Marcellus region. Energy Economics, 47, 112-120.

Sacks, Daniel W., Betsey Stevenson, and Justin Wolfers. 2010. Subjective Well-being, Income, Economic Development and Growth. NBER Working Paper No. 16441.

Sander, William. 2011. Location and Happiness in the United States. Economics Letters, 112(3), 277-279.

Smyth, Russell, Vinod Mishra, and Xiaolei Qian. 2008. The Environment and Well-Being in Urban China. Ecological Economics, 68(1), 547-555.

Texas RRC. 2015. Drilling Permit Data. http://www.rrc.state.tx.us/about-us/resourcecenter/research/data-sets-available-for-purchase/drilling-permit-data/ (Accessed 07/23/15). 
Veenhoven, Ruut, and Michael Hagerty. 2006. Rising Happiness in Nations 1946-2004: A reply to Easterlin. Social Indicators Research, 79(3), 421-436.

Vemuri, Amanda W., and Robert Costanza. 2006. The Role of Human, Social, Built, and Natural Capital in Explaining Life Satisfaction at the Country Level: Toward a National WellBeing Index. Ecological Economics, 58(1), 119-133.

Wang, Qiang, Xi Chen, Awadhesh N. Jha, and Howard Rogers. 2014. Natural Gas from Shale Formation-The Evolution, Evidences and Challenges of Shale Gas Revolution on United States. Renewable and Sustainable Energy Reviews, 30, 1-28.

Weber, Jeremy G. 2012. The Effects of a Natural Gas Boom on Employment and Income in Colorado, Texas, and Wyoming. Energy Economics, 34(5), 1580-1588.

Weber, Jeremy G. 2014. A Decade of Natural Gas Development: The Makings of a Resource Curse? Resource and Energy Economics, 37, 168-183.

Weinstein, Amanda L. 2014. Unconventional Oil and Gas Development's Impact on State and Local Economies. Choices, 29(4), 1-7.

Welsch, Heinz. 2006. Environment and Happiness: Valuation of Air Pollution Using Life Satisfaction Data. Ecological Economics, 58(4), 801-813.

Winkelmann, Liliana, and Rainer Winkelmann. 1998. Why Are the Unemployed So Unhappy? Evidence from Panel Data. Economica, 65(257), 1-15.

Winters, John V. and Yu Li. 2016. Urbanization, Natural Amenities, and Subjective WellBeing: Evidence from US Counties. Urban Studies, Forthcoming, doi:10.1177/0042098016631918.

Xiao, Chenyang and Aaron M. McCright. 2015. Gender Differences in Environmental Concern: Revisiting the Institutional Trust Hypothesis in the USA. Environment and Behavior, 47, 17-37. 
Figure 1: Conventional and Horizontal Drilling Activity in Texas

\section{TX Drilling}

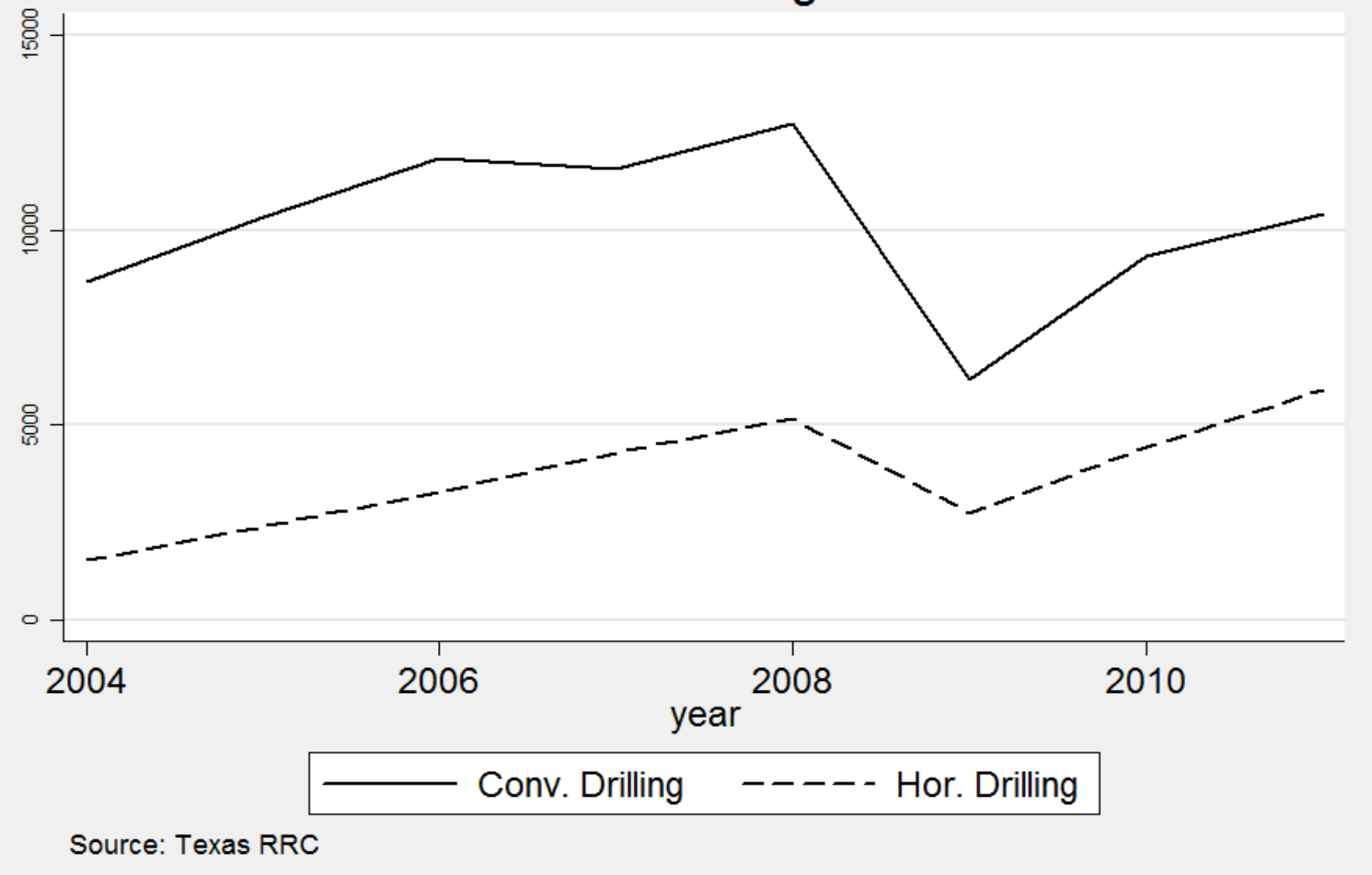


Figure 2: Conventional Wells by County in Year 2010

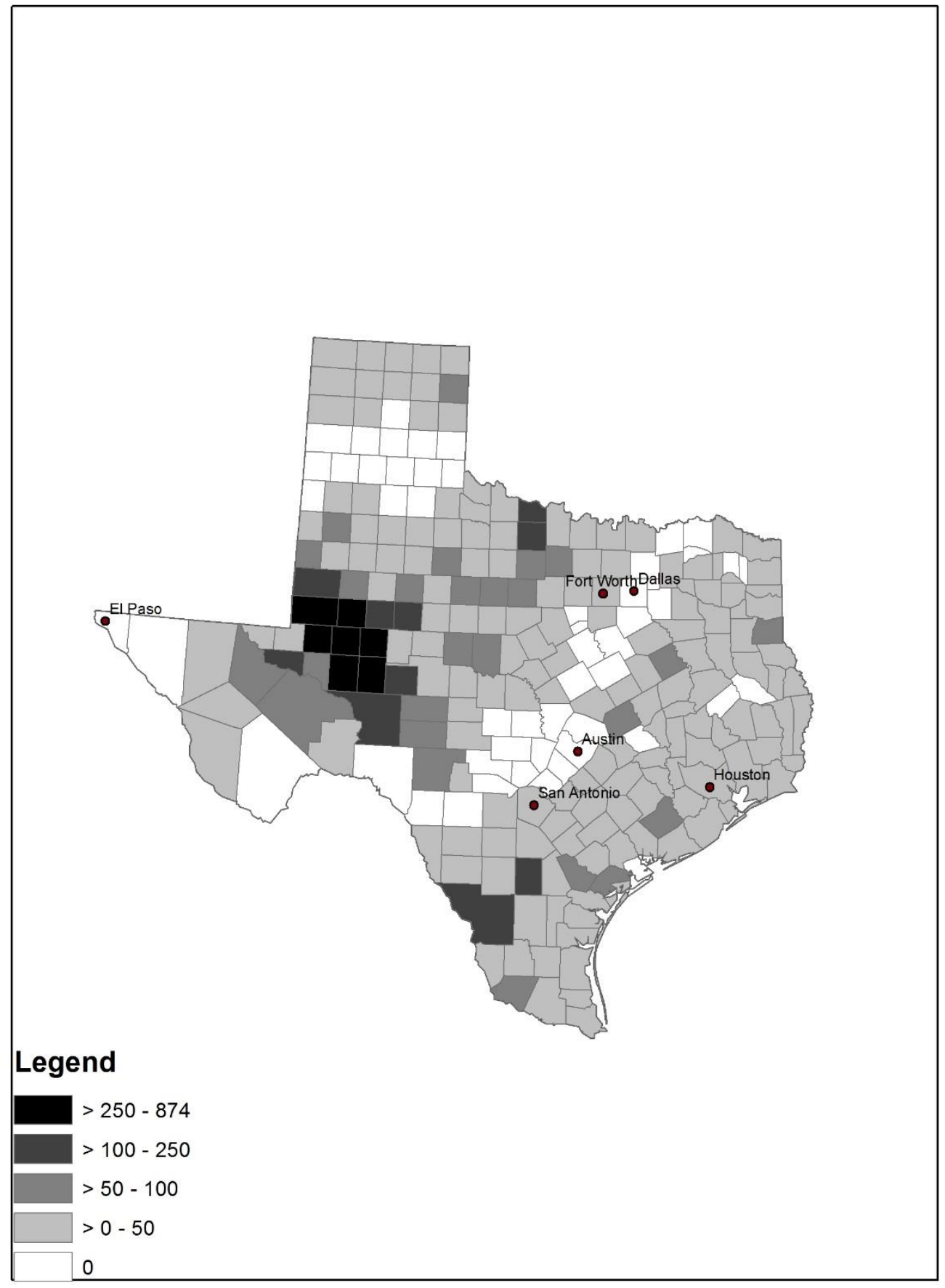


Figure 3: Horizontal Wells by County in Year 2010

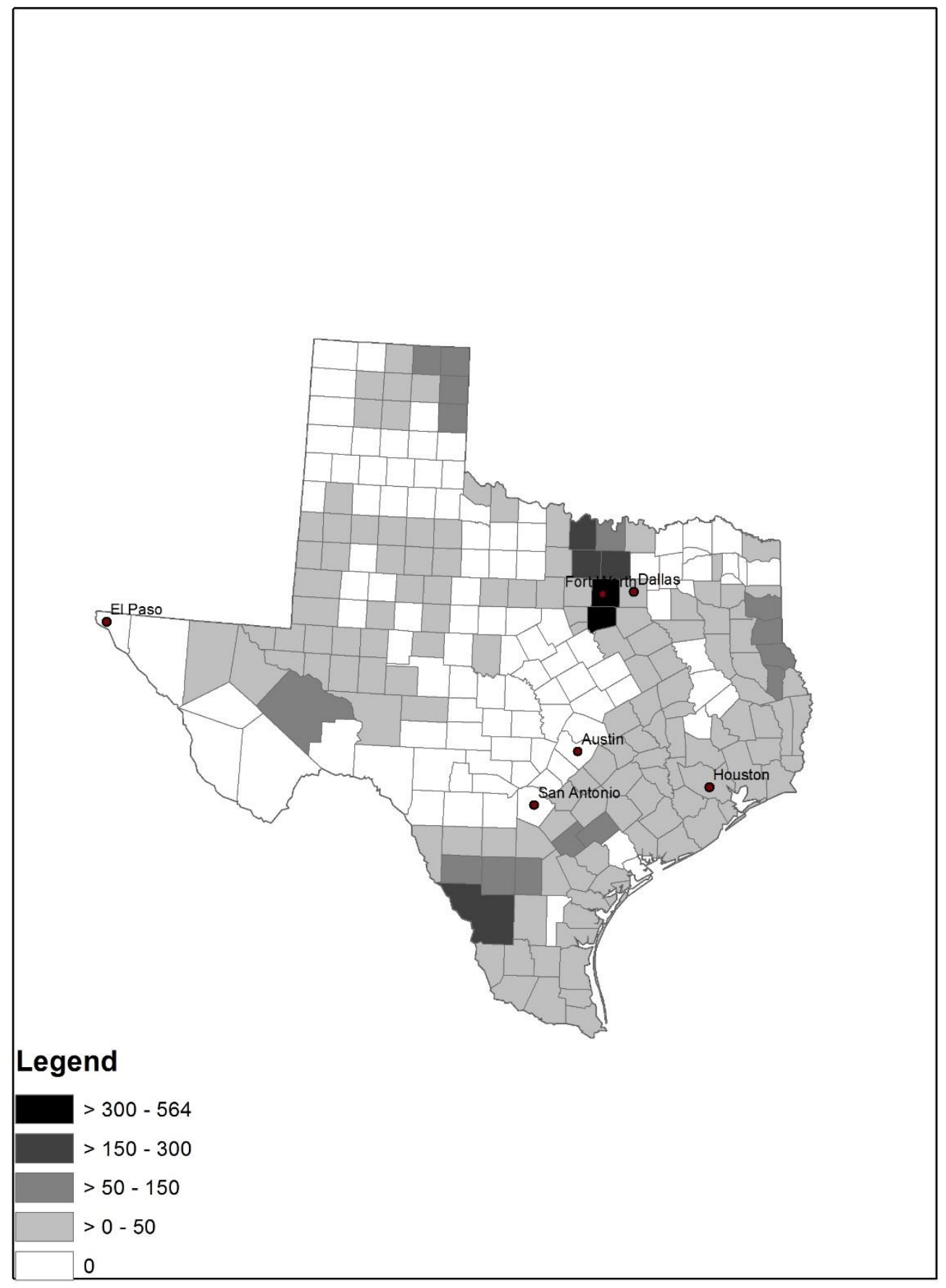


Table 1: Summary Statistics for Full Sample

\begin{tabular}{|c|c|c|c|c|}
\hline & Mean & S.D. & Min & Max \\
\hline \multicolumn{5}{|l|}{ A. Dependent Variables } \\
\hline Life satisfaction & 3.404 & 0.619 & 1 & 4 \\
\hline Bad mental health days & 3.319 & 7.485 & 0 & 30 \\
\hline \multicolumn{5}{|l|}{ B. Main Explanatory Variables } \\
\hline Conventional wells last 12 months & 19.083 & 44.224 & 0 & 547 \\
\hline Horizontal wells last 12 months & 51.380 & 143.883 & 0 & 895 \\
\hline \multicolumn{5}{|l|}{ C. Alternative Explanatory Variables } \\
\hline Conventional wells per land area & 17.750 & 44.200 & 0 & 607 \\
\hline Horizontal wells per land area & 58.824 & 170.325 & 0 & 1227 \\
\hline \multicolumn{5}{|l|}{ D. Control Variables } \\
\hline Black & 0.101 & 0.302 & 0 & 1 \\
\hline Asian & 0.034 & 0.180 & 0 & 1 \\
\hline Hispanic & 0.305 & 0.460 & 0 & 1 \\
\hline Native American & 0.010 & 0.101 & 0 & 1 \\
\hline Other Non-White & 0.018 & 0.132 & 0 & 1 \\
\hline Female & 0.503 & 0.500 & 0 & 1 \\
\hline Ages 23-27 & 0.083 & 0.275 & 0 & 1 \\
\hline Ages 28-32 & 0.106 & 0.307 & 0 & 1 \\
\hline Ages $33-37$ & 0.112 & 0.316 & 0 & 1 \\
\hline Ages $38-42$ & 0.123 & 0.329 & 0 & 1 \\
\hline Ages 43-47 & 0.103 & 0.304 & 0 & 1 \\
\hline Ages 48-52 & 0.095 & 0.293 & 0 & 1 \\
\hline Ages 53-57 & 0.081 & 0.272 & 0 & 1 \\
\hline Ages 58-62 & 0.068 & 0.251 & 0 & 1 \\
\hline Ages 63-67 & 0.048 & 0.215 & 0 & 1 \\
\hline Ages 68-72 & 0.038 & 0.190 & 0 & 1 \\
\hline Ages 73-87 & 0.033 & 0.178 & 0 & 1 \\
\hline Ages 78-82 & 0.024 & 0.152 & 0 & 1 \\
\hline Ages 83-85 & 0.009 & 0.092 & 0 & 1 \\
\hline Highest education: some high school & 0.085 & 0.279 & 0 & 1 \\
\hline Highest education: high school diploma & 0.251 & 0.434 & 0 & 1 \\
\hline Highest education: some college & 0.260 & 0.439 & 0 & 1 \\
\hline Highest education: bachelor's or higher & 0.345 & 0.475 & 0 & 1 \\
\hline Married & 0.636 & 0.481 & 0 & 1 \\
\hline Divorced & 0.089 & 0.284 & 0 & 1 \\
\hline Widowed & 0.046 & 0.210 & 0 & 1 \\
\hline Separated & 0.024 & 0.153 & 0 & 1 \\
\hline Partner & 0.040 & 0.195 & 0 & 1 \\
\hline Two adults in household & 0.558 & 0.497 & 0 & 1 \\
\hline Three or more adults in household & 0.176 & 0.381 & 0 & 1 \\
\hline Ratio of kids to adults in household & 0.486 & 0.686 & 0 & 8 \\
\hline
\end{tabular}

Notes: Total observations equals 59,026 but some values are missing for each of the dependent variables limiting the analytical samples for those variables. 'Wells' include all wells with a spud date in the last 12 months irrespective of whether they were completed. 
Table 2: Summary Statistics for Main Variables by Subsample

Observations Mean Std. Dev. Min Max

\section{A. Full Sample}

Life satisfaction

Bad mental health days

Conventional wells last 12 months

Horizontal wells last 12 months

B. Dallas-Fort Worth Metropolitan Area

Life satisfaction

Bad mental health days

Conventional wells last 12 months

Horizontal wells last 12 months

C. Full Sample Excluding DFW

Life satisfaction

Bad mental health days

Conventional wells last 12 months

Horizontal wells last 12 months

D. Large MSAs Excluding DFW

Life satisfaction

Bad mental health days

Conventional wells last 12 months

Horizontal wells last 12 months

$\begin{array}{ccccc}56,318 & 3.404 & 0.619 & 1 & 4 \\ 57,940 & 3.319 & 7.485 & 0 & 30 \\ 59,026 & 19.083 & 44.224 & 0 & 547 \\ 59,026 & 51.380 & 143.883 & 0 & 895\end{array}$

$\begin{array}{ccccc}8,113 & 3.407 & 0.617 & 1 & 4 \\ 8,392 & 3.119 & 7.158 & 0 & 30 \\ 8,511 & 5.762 & 11.508 & 0 & 113 \\ 8,511 & 172.521 & 240.418 & 0 & 895\end{array}$

$\begin{array}{ccccc}48,205 & 3.403 & 0.619 & 1 & 4 \\ 49,548 & 3.391 & 7.598 & 0 & 30 \\ 50,515 & 23.854 & 50.225 & 0 & 547 \\ 50,515 & 7.988 & 16.615 & 0 & 263\end{array}$

$\begin{array}{lllll}18,861 & 3.404 & 0.624 & 1 & 4 \\ 19,453 & 3.269 & 7.379 & 0 & 30 \\ 19,753 & 9.237 & 10.051 & 0 & 53 \\ 19,753 & 4.850 & 5.017 & 0 & 22\end{array}$

E. Non-MSAs, Small, and Medium MSAs

\begin{tabular}{lccccc} 
Life satisfaction & 29,344 & 3.401 & 0.613 & 1 & 4 \\
Bad mental health days & 30,095 & 3.540 & 7.856 & 0 & 30 \\
Conventional wells last 12 months & 30,762 & 41.671 & 69.973 & 0 & 547 \\
Horizontal wells last 12 months & 30,762 & 11.812 & 23.564 & 0 & 263 \\
\hline
\end{tabular}


Table 3: Effects of Energy Wells on Subjective Well-being Outcomes for Different Samples

(1) (2)

Life Satisfaction Bad Mental Health Days

A. Full Sample

Conventional wells

0.00016

$-0.00037$

$(0.00023)$

Horizontal wells

$-0.00010 * * *$

$(0.00003)$

$(0.00262)$

$0.00152 * * *$

56,318

(0.00031)

Observations

B. Dallas-Fort Worth Metropolitan Area

Conventional wells

$-0.00124 *$

$-0.00528$

$(0.00059)$

$(0.00963)$

$-0.00007 * *$

$0.00242 * * *$

$(0.00003)$

8,113

(0.00034)

8,392

Observations

C. Full Sample Excluding DFW

Conventional wells

0.00028

0.00022

$(0.00025)$

(0.00268)

Horizontal wells

0.00020

$-0.00036$

(0.00043)

(0.00639)

Observations

48,205

49,548

D. Large MSAs Excluding DFW

Conventional wells

0.00172

$-0.02223$

$(0.00154)$

$(0.02509)$

Horizontal wells

0.00485

$-0.02169$

$(0.00310)$

(0.02668)

Observations

18,861

19,453

E. Non-MSAs, Small, and Medium MSAs

Conventional wells

0.00026

0.00142

(0.00024)

(0.00246)

Horizontal wells

0.00004

0.00135

(0.00038)

(0.00586)

29,344

30,095

Observations Notes: standard errors in parentheses are clustered by county. Regressions include controls for
individual characteristics listed in Table 1 and dummies for county and month-year. *Significant at $10 \%$ level; **Significant at 5\% level; ***Significant at $1 \%$ level. 
Table 4: Sensitivity of Main Results to Measuring Wells Relative to County Land Area

(1)

Life Satisfaction Bad Mental Health Days

A. Full Sample

Conventional wells

$$
\begin{aligned}
& -0.00009 \\
& (0.00019)
\end{aligned}
$$

0.00088

$(0.00171)$

Horizontal wells

$-0.00009 * * *$

$0.00121 * * *$

$(0.00002)$

$(0.00029)$

B. Dallas-Fort Worth Metropolitan Area

Conventional wells

$$
\begin{array}{cc}
-0.00108 * & -0.00429 \\
(0.00053) & (0.00868) \\
-0.00006 * & 0.00205 * * * \\
(0.00003) & (0.00029)
\end{array}
$$

Horizontal wells

Notes: standard errors in parentheses are clustered by county. Regressions include controls for individual characteristics listed in Table 1 and dummies for county and month-year.

*Significant at $10 \%$ level; ***Significant at $1 \%$ level. 
Table 5: Heterogeneity of Main Results by Sex

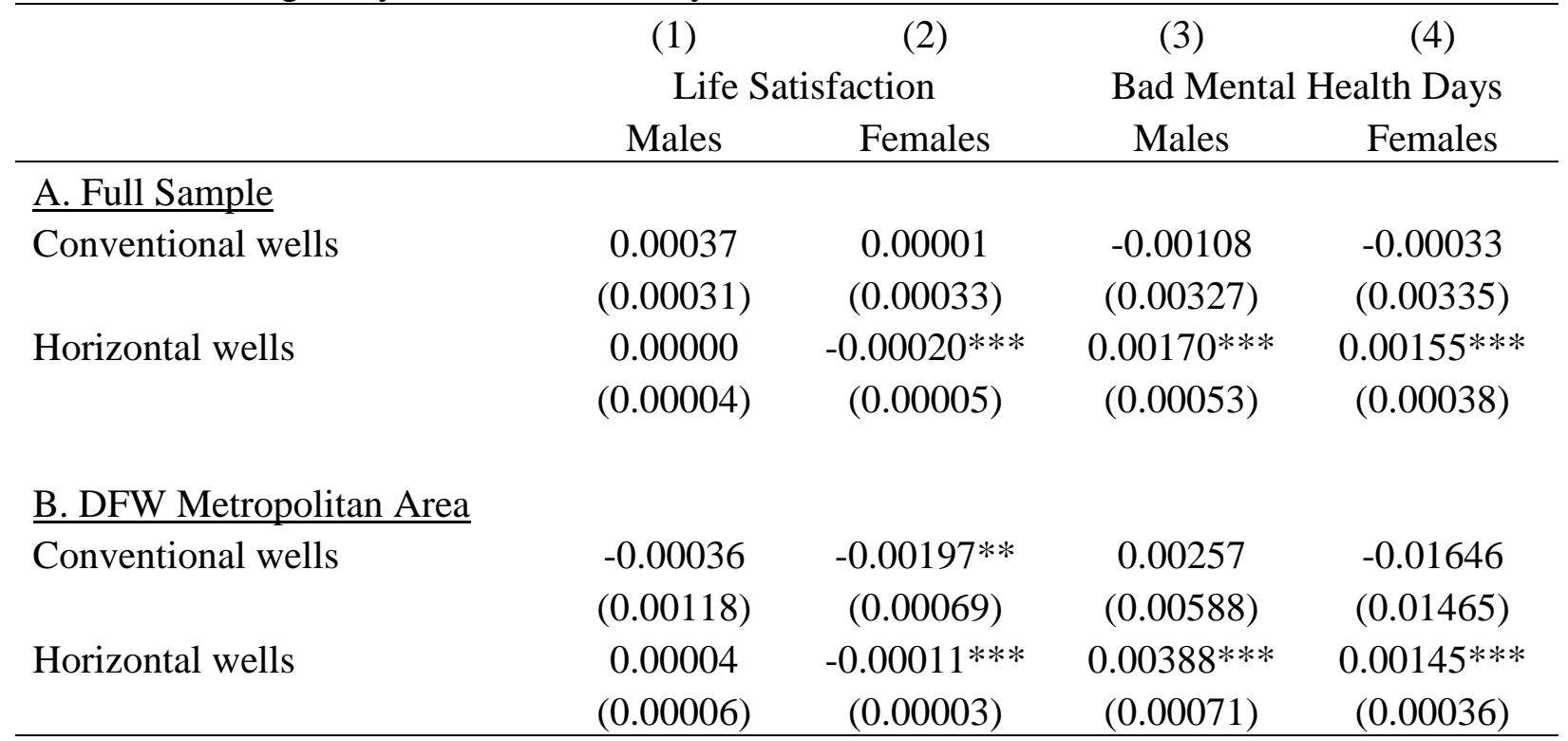

Notes: standard errors in parentheses are clustered by county. Regressions include controls for individual characteristics listed in Table 1 and dummies for county and month-year.

**Significant at $5 \%$ level; ***Significant at $1 \%$ level. 